\title{
Murals meet microbes: at the crossroads of microbiology and cultural heritage
}

\author{
Maria A. Bauer ${ }^{1}$, Katharina Kainz ${ }^{1}$, Christoph Ruckenstuhl ${ }^{1}$, Frank Madeo ${ }^{1-3, *}$ and Didac Carmona- \\ Gutierrez ${ }^{1, *}$ \\ ${ }^{1}$ Institute of Molecular Biosciences, NAWI Graz, University of Graz, Graz, Austria. \\ 2 BioHealth Graz, Graz, Austria. \\ ${ }^{3}$ BioTechMed Graz, Graz 8010, Austria. \\ * Corresponding Authors: \\ Frank Madeo: Humboldtstrasse 50/EG, 8010 Graz, Austria; E-mail: frank.madeo@uni-graz.at; \\ Didac Carmona-Gutierrez; Humboldtstrasse 50/EG, 8010 Graz; E-mail: carmonag@uni-graz.at
}

Our cultural heritage consists of manifold cultural expressions and represents a defining feature of our societies that needs to be further inherited to future generations. Even though humankind always fought a daily struggle for survival, at the same time, it seemed to have a spiritual need that went far beyond mere materialistic satisfaction and nowadays manifests in sometimes very ancient, yet brilliant artistic works. This fundamental legacy is endangered by several instances, including biodeterioration. Indeed, microorganisms play a significant role in the decline of all forms of tangible cultural heritage, including movable, immovable and underwater cultural heritage. Microbial colonization, biofilm formation and damaging metabolite production eventually result in critical decay. Thus, efforts to mitigate the negative impact of damaging microorganisms have been pursued with diverse physical, chemical and biological approaches. Intriguingly, recent advances have unveiled that specific microorganisms and microbial-based technologies also have the potential for cultural heritage preservation and present unique advantages. This short piece provides a quick overview on the duality of microorganisms in the conservation and restoration of cultural heritage.

"He who cannot be far-sighted, Nor three thousand years assay, Inexperienced stays benighted, Let him live from day to day." is a famous quotation from Goethe (rendered to English by J. Whaley) [1]. In other words: somebody is not aware what happened in the last three thousand years, such person remains ignorant, merely surviving from dayto-day. The interest to preserve and inherit cultural value for future generations has accompanied humankind since ancient times. However, it has been constantly and severely challenged not only by the ravages of time, but also by wars, colonial conquests and imperial invasions. The legal grounds to protect this heritage were set in the $19^{\text {th }}$ century and were extended in the $20^{\text {th }}$ century, among others by organizations like the international body UNESCO. Nowadays, it is understood that cultural heritage $(\mathrm{CH})$ refers to manifold aspects with implications on multiple levels. It can be defined as "an expression of the ways of living developed by a community and passed on from generation to generation, including customs, practices, places, objects, artistic expressions, and values." [2]. Accordingly, $\mathrm{CH}$ refers not only to tangible culture, inter alia buildings, wrecks, landscapes, books, or art, but also to intangible culture, which includes e.g., traditions, performing arts, rituals, knowledge as well as skills and practices to produce tangible culture or traditional crafts. Both tangible and intangible $\mathrm{CH}$ need to be safeguarded with active effort so that future generations can enjoy, benefit and learn from the past. $\mathrm{CH}$ not only can evoke certain emotions and bring countries and communities together, it can also be of economic value as a driver of sustainable development and local job creation. Thus, to successfully achieve $\mathrm{CH}$ preservation, the work of different disciplines, including conservator scientists, historians, chemists, microbiologists and many others needs to be connected.

An effective way to preserve intangible $\mathrm{CH}$ is to raise awareness for it and share it with others, i.e. "it must remain relevant to a culture and be regularly practiced and learned within communities and between generations" [3]. The preservation of tangible $\mathrm{CH}$ poses many different challenges, with tangible $\mathrm{CH}$ including movable (paintings, sculptures, coins, manuscripts), immovable (monuments, archaeological sites, etc.) and underwater (shipwrecks, underwater ruins and cities) items. Accordingly, tangible 
$\mathrm{CH}$ comes in the shape of a myriad of different objects, composed of a large range of diverse materials, among others, stone, wood, metal, paper, ceramics, synthetic materials, or organic matter. Additionally, tangible $\mathrm{CH}$ can exist either in controlled and monitored indoor environments, but also in outdoor and under largely uncontrolled conditions. Therefore, all tangible $\mathrm{CH}$ is subject to physical, chemical and/or biological deterioration. Thereby, biodeterioration, and more specifically the impact of microbial biodeteriogenic agents (such as bacteria, algae, lichens, archaea, fungi) represent a central risk for $\mathrm{CH}$ [4].

Microbial deterioration defines any unwanted modification in the characteristics of a given material by the vital activity of microbial organisms [5]. Ultimately, it represents the consequence of microorganisms ensuring their survival in different environments through degradation pathways used for nutrition, morphological adaptations (biofilms) and the generation of metabolic products, which may include acids, solvents, surfactants, or pigments. All may contribute to the deterioration of $\mathrm{CH}$, ranging from slight aesthetic alterations to severe physical and chemical damages [6]. If microbial colonization does have negative consequences for the integrity of $\mathrm{CH}$, steps have to be taken to mitigate the effect.

Accordingly, many efforts have been directed towards both identifying damaging microorganisms and neutralizing their impact on the deterioration of any given item of endangered tangible $\mathrm{CH}$. Regarding microbial identification, three main approaches can be distinguished [7]. (i) Cultureindependent meta-omic analyses, in which the whole microbial community is analyzed using, among others, metagenomics, metatranscriptomics, metabolomics, metaproteomics, PCR amplicons and shotgun sequencing. (ii) Culture-dependent analyses of isolates, which is the most commonly used tool to identify microorganisms on $\mathrm{CH}$ and can include, for example, taxonomic classification (inter alia sequencing-based approaches) or miscellaneous activity tests under different conditions $(\mathrm{pH}$, temperature, etc.) $[8,9]$. This approach is simple, cheap, and can be accomplished, for instance, by museum workers with a basic training. However, many $\mathrm{CH}$-resident microorganisms are unfortunately not cultivable. Therefore, a combined strategy with meta-omic analyses would provide the most reliable results. As a third identification approach, changes in the structure and composition of degraded or renovated material can be examined by (iii) physico-chemical analyses. These include, among others, scanning electron microscopy (coupled with energy-dispersive X-ray spectroscopy), transmission electron microscopy, fluorescence microscopy, Raman spectroscopy, Fourier transform coupled infrared spectroscopy, ion chromatography and microtomography. Some of these methods not only help monitoring the levels of microbial contamination, but may also reveal the actual state of damage of the analyzed artwork [7].

Upon recognition of the microbial threat, strategies for the removal of the identified microorganisms or for the neutralization of their negative effects need to be found. A plethora of traditional and novel methods and techniques are used, including physical methods (e.g., gamma radiation and UV-C irradiation, low pressure water rinsing, steam cleaning, laser cleaning, heat-shocking, microwave and dry-ice treatment) as well as chemical treatments (traditional biocides and nanoparticles). Additionally, biological procedures have been developed, including biocidal treatments with natural compounds $[6,10]$ or, more recently, biocleaning methods, where enzymatic or organismal treatment is used for the removal of specific metabolites, substrates and/or other damaging material (see below) [11-19]. Unfortunately, conventional physico-chemical methods are not always effective and in some cases may even be dangerous for the treated $\mathrm{CH}$. Some chemical treatments (nanoparticles, traditional chemical biocides) on stone $\mathrm{CH}$, for instance, have been shown not to be sufficiently selective and consequently damage the stone surfaces $[11,20-23]$. Other procedures need to be applied repeatedly (e.g., mechanical removal, gamma radiation, UV-C irradiation) and may therefore damage stone surfaces as well as organic heritage material like wood, leather, parchment, and textiles [6]. In addition, some active compounds used for $\mathrm{CH}$ preservation can be toxic and not degradable, or can be persistent in and thus negatively impact the environment. Thus, it continues to be an important task to refine existent $\mathrm{CH}$ preservation methods and to further elucidate novel (and mild) treatments with high effectivity that neither pose a health risk nor compromise the environment.

While efforts to counteract damaging microbial activity on $\mathrm{CH}$ remain an important issue, microorganisms may themselves also be helpful for heritage conservation and restoration. In fact, the metabolism of many microorganisms may be deleterious on one substrate, but can be positively exploited on a different substrate. For example, while bacterial sulfate reduction accounts for biocorrosion of iron and iron alloys $[24,25]$, black crusts can be removed from stone artwork with the help of distinct microorganisms that use sulfate reduction pathways $[14,20]$. In fact, biocleaning methods have been developed, where selected bacteria and fungi as well as microbial enzymes are used for the removal of damaging sulfates, nitrates, animal glue, caseine as well as organic matter from stone [11-16] or other surfaces [17-19, 26, 27]. Biocleaning is less invasive and an environmentally friendly alternative, since the microorganisms used act similarly on $\mathrm{CH}$ as in their natural environment. Examples include the bacteria Pseudomonas denitrificans, which has been applied to eliminate nitrate salts [28], Desulfovibrio vulgaris, which have been used to remove sulfates [15]. or Pseudomonas stutzeri which can be employed for removal of organic matter [19]. Moreover, microbial treatment may be effective through other processes, such as biological patination of metals by Beauveria bassiana [29], or carbonatogenesis in self-healing concrete mediated by bacterial spores of Bacillus alkalinitrilicus [30]. Additionally, while microbial biofilms mainly do have deteriorating effects on $\mathrm{CH}$, some biofilms, especially those generated by particular cyanobacteria and fungi, have been shown to conserve lithic 
materials by generating a stable layer that contributes to, for example, case-hardening of sandstone and protects the surfaces from further decomposition [31-33]. Moreover, natural biofilms can be more compatible with the surface of $\mathrm{CH}$ than traditionally used protective coatings [6].

Biocleaning is inexpensive, easy to use and has a low negative impact on $\mathrm{CH}$, especially on stoneworks, mural paintings and frescoes, but also on paper, wood, waterlogged wood and iron [17]. Nevertheless, it presents a number of limitations. If water is applied on $\mathrm{CH}$ surfaces during biocleaning treatment, it may cause leaching or salt solubilization, and also may negatively affect the state of $\mathrm{CH}$ materials. To circumvent this problem, the so-called dry biocleaning approach has been devised, where dehydrated microbial cells could be employed without using free water or gel-based matrices. In this respect, the baker's yeast Saccharomyces cerevisiae has recently been successfully implemented on $\mathrm{CH}$ preservation [11]. Of note, dry biocleaning could be particularly efficient in removing alterations on highly ornamented stoneworks [11]. Still, the application of microorganisms - generally conceived as $\mathrm{CH}$ deteriorating agents - continues to meet some reluctancy, which tends to favor the chemical and mechanical treatments [28]. Indeed, more work is needed to study the safety of biocleaning technology, in particular with respect to the $\mathrm{CH}$ objects themselves, but also regarding possible medical and environmental hazards [34]. Thus, the close monitorization of both short-term and long-term effects of bio-restored $\mathrm{CH}$ will help clarify whether this method is indeed an overall softer and safer process. This will also help decipher if microbial agents used for biocleaning need to be removed after usage at the $\mathrm{CH}$ site [17] or may remain under constant surveillance [34]. In any case, for the further use and acceptance of biocleaning strategies, it will be important to establish techniques and protocols to define if a given microorganism does cause biodeterioration, promotes only aesthetic alterations or, in fact, acts in a bioprotective manner [6].

\section{REFERENCES}

1. Goethe JW von (1819). West-oestlicher Divan; West-eastern divan, rendered to English by J Whaley (1974), Wolff, London. p 91.

2. Hartmann R (2020). Heritage and Economy. In: Kobayashi A, editor Int. Encycl. Hum. Geogr. Second Ed. Elsevier, Oxford; pp 369-372.

3. Alivizatou M (2011). Intangible Heritage and Erasure: Rethinking Cultural Preservation and Contemporary Museum Practice. Int J Cult Prop 18(1): 37-60. doi: 10.1017/S094073911100004X

4. Ranalli G, Zanardini E, and Sorlini C (2009). Biodeterioration - Including Cultural Heritage. In: Schaechter M, editor Encycl. Microbiol. Third Ed. Academic Press, Oxford; pp 191-205. doi: 10.1016/b978012373944-5.00132-2

5. Allsopp D, Seal KJ, and Gaylarde CC (2004). Introduction to biodeterioration, 2nd ed. Cambridge University Press, Cambridge ; New York.

6. Cappitelli F, Cattò C, and Villa F (2020). The Control of Cultural Heritage Microbial Deterioration. Microorganisms 8(10): 1542. doi: 10.3390/microorganisms8101542
Microbiology and $\mathrm{CH}$ cross paths at different levels: on the one hand, microbial activities fundamentally endanger $\mathrm{CH}$, while, on the other hand, specific microorganisms can be employed to protect $\mathrm{CH}$. In its Special Issue on $\mathrm{CH}, \mathrm{Mi}$ crobial Cell has compiled and continues to gather a series of (research and review) articles that mirror this duality. The Special Issue further aims to serve as a platform for further scientific exchange in $\mathrm{CH}$ research: also for microbiologists, preserving the past is a cardinal task for a flourishing future.

\section{ACKNOWLEDGMENTS}

F.M. is grateful to the Austrian Science Fund FWF (SFB LIPOTOX F3007 \& F3012, DK-MCD W1226, as well as grants P29203, P29262, P27893, and P31727) and the Austrian Federal Ministry of Education, Science and Research, as well as the University of Graz for grants "Unkonventionelle Forschung-InterFast and Fast4Health" as well as "flysleep" (BMWFW-80.109/0001-WF/V/3b/2015). We acknowledge the support of the field of excellence BioHealth, NAWI Graz, and the BioTechMed-Graz flagship project "EPIAge."

\section{CONFLICT OF INTEREST}

No competing financial interests exist.

\section{COPYRIGHT}

(C) 2021 Bauer et al. This is an open-access article released under the terms of the Creative Commons Attribution (CC BY) license, which allows the unrestricted use, distribution, and reproduction in any medium, provided the original author and source are acknowledged.

Please cite this article as: Maria A. Bauer, Katharina Kainz, Didac Carmona-Gutierrez and Frank Madeo (2021). Murals meet microbes: at the crossroads of microbiology and cultural heritage. Microbial Cell 8(12): 276-279. doi: 10.15698/mic2021.12.765

7. Pyzik A, Ciuchcinski K, Dziurzynski M, and Dziewit L (2021). The Bad and the Good-Microorganisms in Cultural Heritage EnvironmentsAn Update on Biodeterioration and Biotreatment Approaches. Materials 14(1): 177. doi: 10.3390/ma14010177

8. Savković Ž, Stupar M, Unković N, Ivanović Ž, Blagojević J, Vukojević J, and Ljaljević Grbić M (2019). In vitro biodegradation potential of airborne Aspergilli and Penicillia. Naturwissenschaften 106(3-4): 8. doi: 10.1007/s00114-019-1603-3

9. Pavić A, Ilić-Tomić T, Pačevski A, Nedeljković T, Vasiljević B, and Morić I (2015). Diversity and biodeteriorative potential of bacterial isolates from deteriorated modern combined-technique canvas painting. Int Biodeterior Biodegrad 97: 40-50. doi: 10.1016/j.ibiod.2014.11.012

10. Fernandes $P$ (2006). Applied microbiology and biotechnology in the conservation of stone cultural heritage materials. Appl Microbiol Biotechnol 73(2): 291-296. doi: 10.1007/s00253-006-0599-8 
11. Ranalli G, Bosch-Roig P, Crudele S, Rampazzi L, Corti C, and Zanardini $E$ Dry biocleaning of artwork: an innovative methodology for Cultural Heritage recovery? Microbial Cell 8(5): 91-105. doi: 10.15698/mic2021.05.748

12. Gauri KL, Chowdhury AN, Kulshreshtha NP, and Punuru AR (1989). The sulfation of marble and the treatment of gypsum crusts. Stud Conserv 34(4): 201-206. doi: 10.1179/sic.1989.34.4.201

13. Ranalli G, Chiavarini M, Guidetti V, Marsala F, Matteini M, Zanardini $E$, and Sorlini $C$ (1997). The use of microorganisms for the removal of sulphates on artistic stoneworks. Int Biodeterior Biodegrad 40(2): 255-261. doi: 10.1016/S0964-8305(97)00054-1

14. Cappitelli F, Zanardini E, Ranalli G, Mello E, Daffonchio D, and Sorlini C (2006). Improved methodology for bioremoval of black crusts on historical stone artworks by use of sulfate-reducing bacteria. Appl Environ Microbiol 72(5): 3733-3737. doi: 10.1128/AEM.72.5.37333737.2006

15. Alfano G, Lustrato G, Belli C, Zanardini E, Cappitelli F, Mello E, Sorlini $C$, and Ranalli G (2011). The bioremoval of nitrate and sulfate alterations on artistic stonework: The case-study of Matera Cathedral after six years from the treatment. Int Biodeterior Biodegrad 65(7): 1004-1011. doi: 10.1016/j.ibiod.2011.07.010

16. Cappitelli F, Toniolo L, Sansonetti A, Gulotta D, Ranalli G, Zanardini $E$, and Sorlini C (2007). Advantages of using microbial technology over traditional chemical technology in removal of black crusts from stone surfaces of historical monuments. Appl Environ Microbiol 73(17): 5671-5675. doi: 10.1128/AEM.00394-07

17. Ranalli G, and Zanardini E (2021). Biocleaning on Cultural Heritage: new frontiers of microbial biotechnologies. J Appl Microbiol 131(2): 583-603. doi: 10.1111/jam.14993

18. Lustrato G, Alfano G, Andreotti A, Colombini MP, and Ranalli G (2012). Fast biocleaning of mediaeval frescoes using viable bacterial cells. Int Biodeterior Biodegrad 69: 51-61. doi: 10.1016/j.ibiod.2011.12.010

19. Ranalli G, Alfano G, Belli C, Lustrato G, Colombini M p., Bonaduce I, Zanardini E, Abbruscato $P$, Cappitelli F, and Sorlini C (2005). Biotechnology applied to cultural heritage: biorestoration of frescoes using viable bacterial cells and enzymes. J Appl Microbiol 98(1): 73-83. doi: 10.1111/j.1365-2672.2004.02429.x

20. Polo A, Cappitelli F, Brusetti L, Principi P, Villa F, Giacomucci L, Ranalli G, and Sorlini C (2010). Feasibility of removing surface deposits on stone using biological and chemical remediation methods. Microb Ecol 60(1): 1-14. doi: 10.1007/s00248-009-9633-6

21. Gioventù E, Lorenzi PF, Villa F, Sorlini C, Rizzi M, Cagnini A, Griffo A, and Cappitelli $F$ (2011). Comparing the bioremoval of black crusts on colored artistic lithotypes of the Cathedral of Florence with chemical and laser treatment. Int Biodeterior Biodegrad 65(6): 832-839. doi: 10.1016/j.ibiod.2011.06.002

22. Troiano F, Gulotta D, Balloi A, Polo A, Toniolo L, Lombardi E, Daffonchio D, Sorlini C, and Cappitelli F (2013). Successful combination of chemical and biological treatments for the cleaning of stone artworks. Int Biodeterior Biodegrad 85: 294-304. doi: 10.1016/j.ibiod.2013.08.011

23. Palla F, Bruno M, Mercurio F, Tantillo A, and Rotolo V (2020). Essential Oils as Natural Biocides in Conservation of Cultural Heritage. Mol Basel Switz 25(3): E730. doi: 10.3390/molecules25030730

24. Dinh HT, Kuever J, Mussmann M, Hassel AW, Stratmann M, and Widdel $F$ (2004). Iron corrosion by novel anaerobic microorganisms. Nature 427(6977): 829-832. doi: 10.1038/nature02321

25. Videla HA, and Herrera LK (2005). Microbiologically influenced corrosion: looking to the future. Int Microbiol Off J Span Soc Microbiol 8(3): 169-180. PMID: 16200495

26. Bosch Roig M del P, Regidor Ros JL, Soriano Sancho MP, Domenech Carbo MT, and Montes Estellés RM (2010). Ensayos de biolimpieza con bacterias en pinturas murales. In: Arché. Instituto Universitario de Restauración del Patrimonio de la UPV; pp 117-124.

27. Mazzoni M, Alisi C, Tasso F, Cecchini A, Marconi P, and Sprocati AR (2014). Laponite micro-packs for the selective cleaning of multiple coherent deposits on wall paintings: The case study of Casina Farnese on the Palatine Hill (Rome-Italy). Int Biodeterior Biodegrad 94: 1-11. doi: 10.1016/j.ibiod.2014.06.004

28. Romano I, Abbate M, Poli A, and D'Orazio L (2019). Bio-cleaning of nitrate salt efflorescence on stone samples using extremophilic bacteria. Sci Rep 9(1): 1668. doi: 10.1038/s41598-018-38187-x

29. Joseph E, Cario S, Simon A, Wörle M, Mazzeo R, Junier P, and Job D (2012). Protection of Metal Artifacts with the Formation of MetalOxalates Complexes by Beauveria bassiana. Front Microbiol 2: 270. doi: 10.3389/fmicb.2011.00270

30. Wiktor V, and Jonkers HM (2011). Quantification of crack-healing in novel bacteria-based self-healing concrete. Cem Concr Compos 33(7): 763-770. doi: 10.1016/j.cemconcomp.2011.03.012

31. González-Gómez WS, Quintana P, Gómez-Cornelio S, García-Solis C, Sierra-Fernandez A, Ortega-Morales $O$, and De la Rosa-García SC (2018). Calcium oxalates in biofilms on limestone walls of Maya buildings in Chichén Itzá, Mexico. Environ Earth Sci 77(6): 230. doi: 10.1007/s12665-018-7406-6

32. Favero-Longo SE, and Viles HA (2020). A review of the nature, role and control of lithobionts on stone cultural heritage: weighing-up and managing biodeterioration and bioprotection. World J Microbiol Biotechnol 36(7): 100. doi: 10.1007/s11274-020-02878-3

33. Viles HA, and Goudie A (2004). Biofilms and case hardening on sandstones from Al-Quwayra, Jordan. Earth Surf Process Landf 29: 1473-1485. doi: 10.1002/esp.1134

34. Bosch-Roig P, and Ranalli G (2014). The safety of biocleaning technologies for cultural heritage. Front Microbiol 5: 155. doi: 10.3389/fmicb.2014.00155 